\title{
463 岩床式蓄熱槽に関する実験的研究
}

Experimental Study on Thermal Performance of Rock Bed Heat Storage System

\author{
鈴木 淳 (室蘭工業大学) 松坂 覚 (室蘭工業大学) ヒムサール アムバリタ (室蘭工業大学) \\ 勇田 敏男 (東京電機大学) 佐藤 真由美（室蘭工業大学）岸浪 䋘機（室蘭工業大学）
}

\author{
Jụ SUZUKI*, Satoru NATSUSAKA*, Himsar AMBARITA*, \\ Tosio YUTA**, Mayumi SATOU*, Kouki KISHINAMI*
}

*Muroran Institute of Technology,, 27-1 Mizumoto-cho, Muroran $\quad 050-8585$
** Tokyo Denki University

\section{Abstract}

Rock-Beds are generally considered to be the most suitable storage units for heating systems combined with air heated type of solar collector in cold regions. Thermal characteristics of rock bed storage tanks were investigated by experiments using inline and stagger brick's arrangement for storage units of sub-scale model and by numerical analysis for basic models corresponding to experimental condition.

The effect of bricks aligned/stagger arrays and it's dimensions on thermal storage and convection behavior in charging/discharging process were discussed, and the stagger arrangement of the bricks was cleared to be the most effective in storage performance due to the convective heat transfer enhancement and the area increasing.

Keyword: Rock Bed Heat Storage System, Charging, Discharging, Brick Array, Effective Energy.

\section{1. 緒言}

太陽エネルギは膨大かつ非枯渴性で，持続再生可能なエ ネルギ資源として，将来採暖熱利用システムとして積極的 な利用をはかる必要がある。しかし季節や天候，時間によ って日射量が大きく変動してしまう不安定性やエネルギ密 度，面積当たりの熱量が低いことなどが大きな問題点とな っている.太陽熱の有効利用には，優秀な集熱器に加えて, 採暖エネルギーの不安定性を吸収する性能がよく低コスト な蓄熱方法の研究開発が必須の課題となる．そこで本研究 室では，寒冷地における太陽熱暖房システムとして空気加 熱式太陽エネルギ集熱器と岩床式蓄熱槽を組み合わせる採 暖システムに関し，研究を進めてきた。

本論では岩床式蓄熱槽に着目し，その熱的および蓄熱・ 放熱特性に関して, 蓄熱媒体として千鳥, 碁盤目配列のレ ンガを用いた場合について 主に配置，配列による対流挙 動と，蓄熱槽の伝熱的挙動や蓄熱特性を実験的，数値的に 明らかにした結果について報告する。

\section{2. 実験装置および実験方法}

Fig.1 は本実験装置の概略図である。本装置は主に岩床 式固体蓄熱槽，蓄熱媒体循環用の遠心式送風機，流量測定 用オリフィス板, 空気の流路変換器, 熱源から成る.

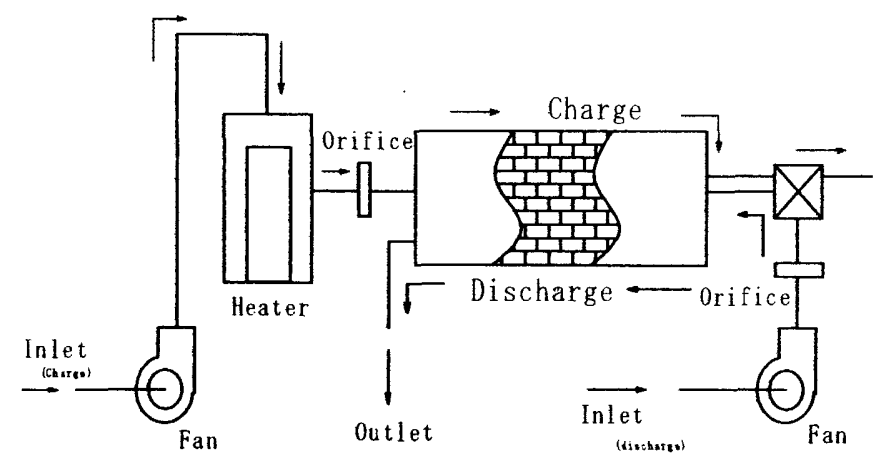

Fig.1 Outline of Experimental Apparatus
本実験では図示のように蓄熱，放熱過程は流れを所定時 間毎に変えることで行い蓄熱媒体であるレンガの配列を課 題としていずれの場合も 27 個使用した。レンガ配列は Array1 Array4 の種類であり，その配列について以下に説 明する．また，Fig.2(a) Fig.2(d)にその配列図をそれぞれ 示す.

Array 1：レンガを縦に置き，幅方向に 3 個，長さ方向に 9 個, 碁盤目配列

Array2 : レンガを縦に置き，蓄熱槽入口側から幅方向に順 に 2 個，3 個，4個の千鳥配列させたものを 1 ブ ロックを長さ方向に 3 ブロック並べた配列

Array3：レンガを横に置き, 幅方向に 3 個, 長さ方向に 3 個並へ，高さ方向に 3 段重小た基盤目配列

Array4 : Array 3の各ブロック 2 段目を側面側にずらし, 千鳥配列させた配列

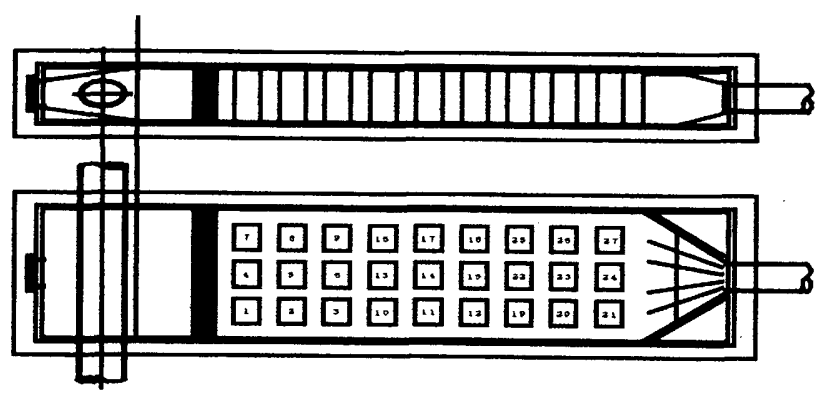

Fig.2(a) Array 1(Inline Arrang.)

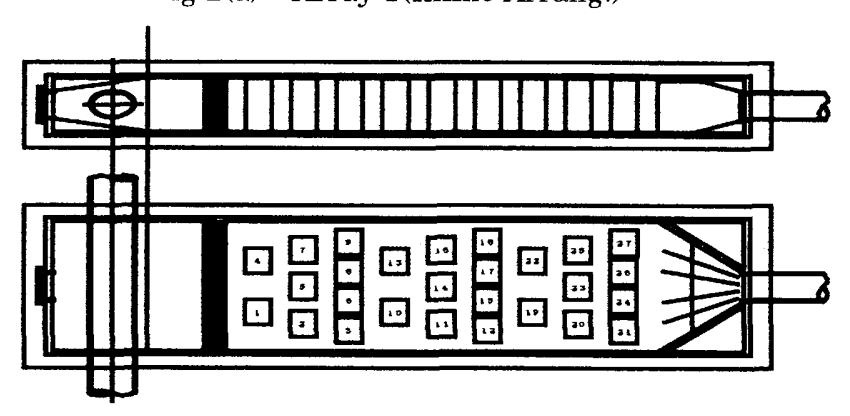

Fig.2(b) Array 2(Stagger Arrang.)

[No.05-13] 日本機械学会第 15 回環境工学総合シンポジウム 2005 講演論文集 $[2005.7 .7,8 \cdot$ 室蘭] 


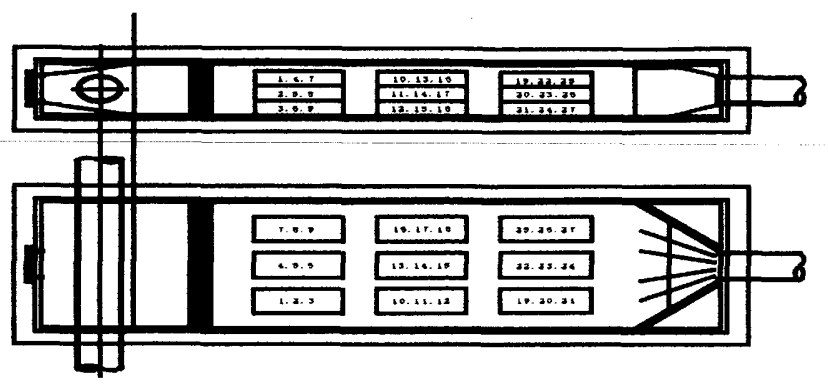

Fig.2(c) Array 3(Pile Arrang. I )

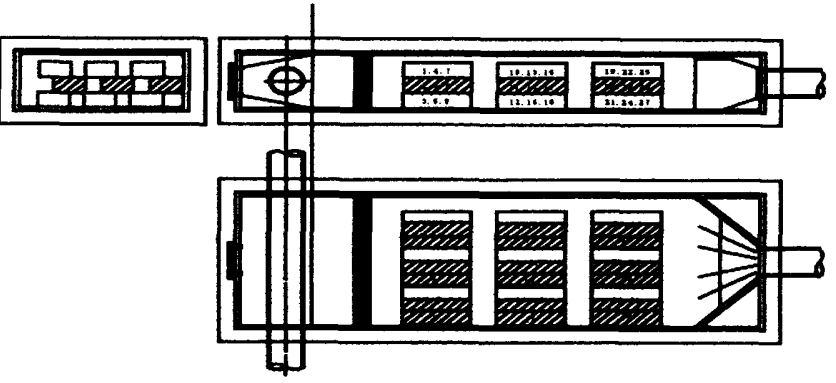

Fig.2(d) Array 4 (Pile Arrang. II)

システム全体における温度測定点は全 49 点である，全 ての温度計測は T 型（銅ーコンスタンタン）熱電対による 計測値をリモートスキャナにより収録した。 このうち 24 点は，固体蓄熱槽内の長さ・高さおよび幅方向の温度分布 測定に，3 点は蓄熱槽内壁の温度測定に，3 点は蓄熱槽外 壁の温度測定に使用される， 7 点は，蓄熱槽入口および出 口における空気温度の測定に用いている．また 1 点は周囲 温度の測定に, 2 点は蓄熱槽入口側・出口側オリフィスに おける空気温度の測定に使用される，その他 5 点はシステ ム全体の温度分布を確認するために用いた，実験の 1 サイ クルを蓄熱過程, 放熱過程の 2 段階に分け，それぞれの時 間配分を, 5 時間, 3.5 時間と設定した. 空気の質量流量を 操作し， 4 種類の配列の場合について各点における過渡温 度を測定する方法で実験を行った。

本実験において，蓄熱過程での岩床の蓄熱量と，放熱時 に空気が岩床から得たエネルギを計算する際に用いた算定 式を(1),(2)式としてそれぞれ以下に示す.

$$
\begin{aligned}
& Q_{\text {store }, r}=\sum_{i=1}^{n} \operatorname{Crmr}(\operatorname{Tr}(i, \tau=\text { end })-\operatorname{Tr}(i, \tau=0)) \quad[\mathrm{kJ}] \\
& Q_{\text {dischar }, a}=\int \dot{m} \alpha C P a\left(T a_{-} \text {in }(\tau)-T_{a_{-} \text {out }}(\tau)\right) d \tau \quad[\mathrm{kJJ}]
\end{aligned}
$$

ここで， $\mathrm{Q}$ はレンガの比熱 $[\mathrm{J} / \mathrm{kg} \cdot \mathrm{K}], \mathrm{mr}$ はレンガの質 量 $[\mathrm{kg}]$, ma は空気の質量流量 $[\mathrm{kg} / \mathrm{s}]$, Cpa は空気の定圧比 熱[J/kg・K]である。また（1)式では蓄熱開始時と終了時の レンガの温度差(2)式では蓄熱槽入口空気と出口空気の温 度差を使用している。

\section{3. 数值計算による基本的な流れ場の考察・検討}

Fig.3，Fig.4 は数值計算による流線と圧力場を示す. 蓄 熱槽入口温度を $50\left[{ }^{\circ} \mathrm{C}\right]$, レンガの初期温度 $20\left[{ }^{\circ} \mathrm{C}\right]$, 流速を $0.1[\mathrm{~m} / \mathrm{s}]$ ，レンガの個数は 30 個で繸置きに設定した. レン ガ配列は基本として碁盤目と千鳥配列の 2 種類とした.

碁盤目：レンガを縦に置き，幅方向に 6 個，長さ方向に
5 個，直線的に並べた場合

千鳥配列：レンガを縦に置き，幅方向に 6 個，長さ方向に 5 個並心，長さ方向に $2 ， 4$ 番目の列をずらし千 鳥配列の場合

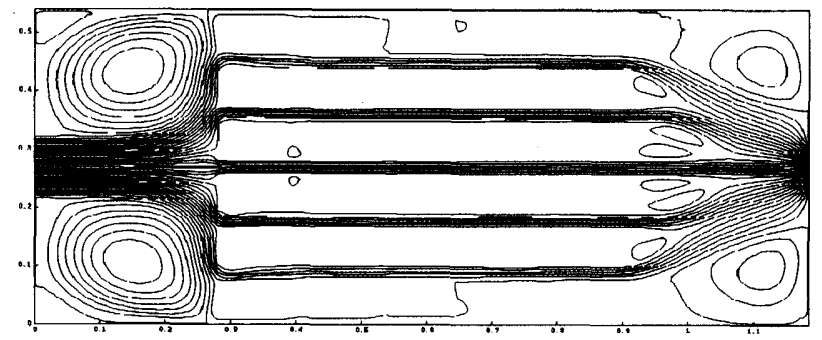

(a)Inline Array

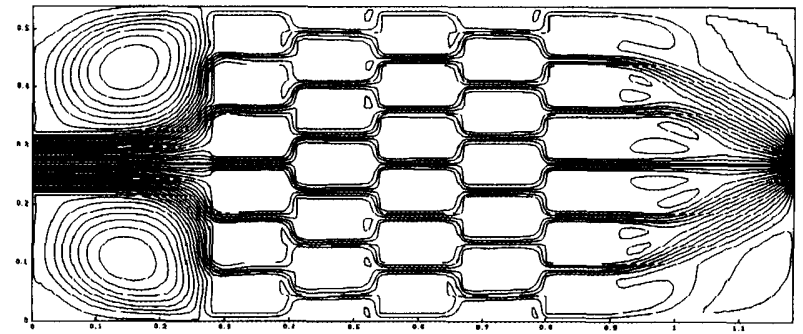

(b)Stagger Array

Fig. 3 Stream Line of Air Flow in Rock Bed

千鳥配列の場合は流れ方向，垂直方向ともに空気が一様 に流れているのに対し，碁盤目の場合は岩床間の垂直方向 の速度は全く認められない。このことから，千鳥配列のほ うがより広い面積で空気とレンガ間の熱交換が可となり， 結果として蓄熱量が大きくなることがわかる。

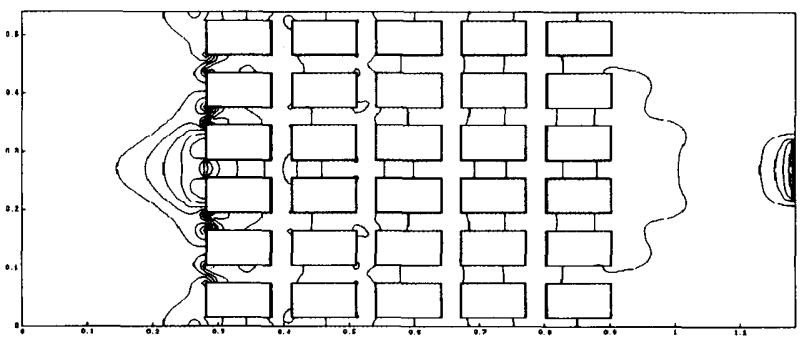

(a)Inline Array

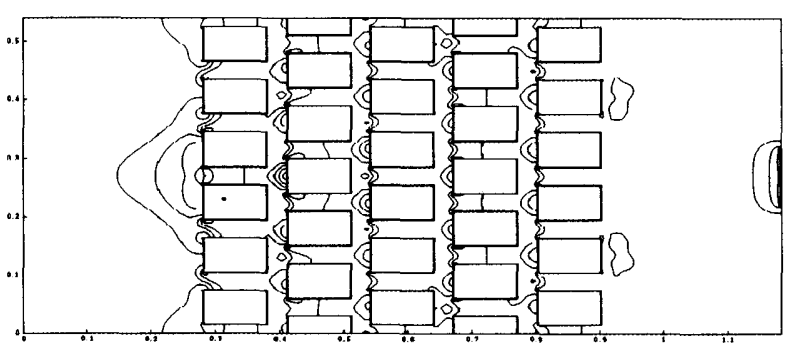

(b)Stagger Array

Fig.4 Pressure Distribution in Rock Bed

碁盤目配列において先の図で明らかにしたように流れは 配列方向にのみ流れ，圧力はこの方向にのみ分布し垂直方 向に流れがないため圧力差が生じない.しかし千鳥の場合， すべての方向に流れに沿った圧力分布を示すが，流れの衝 突部（流れの方向が急激に変わる所）で圧力変化が著しい ことが認められる.千鳥配列の場合の圧力損失は碁盤目の 
場合より全体的に増大し，最大で碁盤目配列が $0.024[\mathrm{~Pa}]$, 千鳥配列が $0.035[\mathrm{~Pa}]$ と約 1.5 倍となっている.

\section{4. 実験結果および検討・考察}

Fig.5(a)，(b)は蓄熱・放熱過程における蓄熱槽入口・出 口空気の温度履歴である。流量は $0.01[\mathrm{~kg} / \mathrm{s}]$ とした。

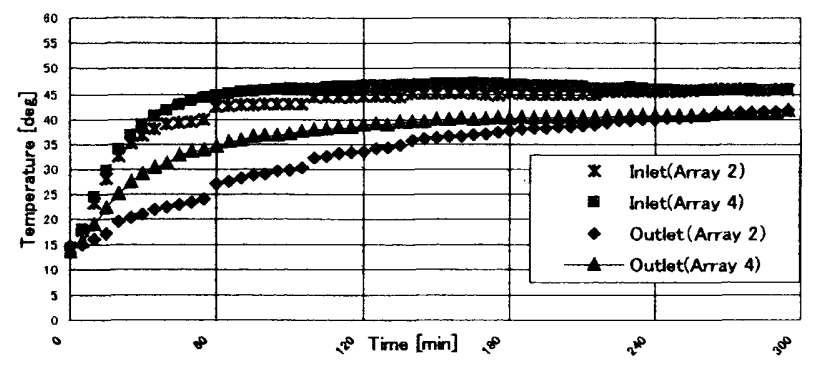

(a) Charging

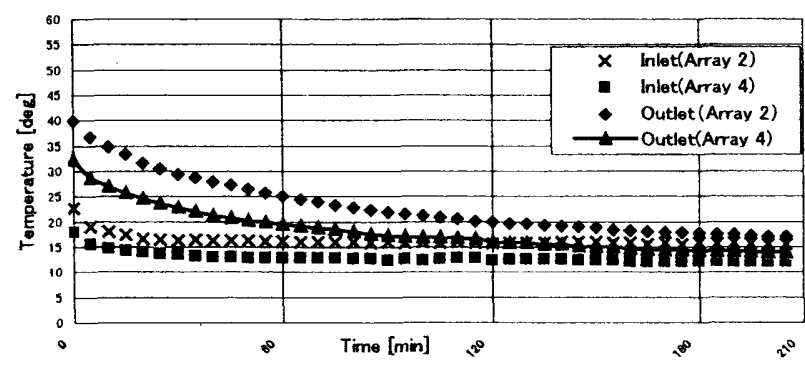

(b) Discharging

Fig.5 Transient Temperature of Air Inlet and Outlet

Fig.5(a)の出口温度を比較してみると，レンガを縦に置 いた場合では，蓄熱開始から終了まで，ごく緩やかな曲線 を描きながら温度が上昇しており，上昇が継続する傾向が 見られるのに対し，横に置いた Fig.5(a)の場合では，蓄熱 初期で急激な温度上昇が見られ，その後，ほぼ一定の值を 保っている．これは，縦置きの場合と比へ，横置きの場合 には加熱空気とレンガ間の熱交換が十分に行われていない ことを示している．横置きに比べ縦置きの場合, 熱媒体空 気との対流伝熱面積が大きくとれることに加え，千鳥配列 とすれば，流れの解析結果が示すように空気の熱伝達が全 てのレンガ面において行われるため最大の蓄熱, 放熱効果 を得ている。

この蓄熱槽を暖房として使用する場合，蓄熱槽出口の空 気温度が $20\left[{ }^{\circ} \mathrm{C}\right]$ 以下になると, 暖房としての役割を果たさ なくなるという観点から Fig.5(b)を見てみると，それぞれ のレンカ配置において，蓄熱槽出口の空気温度が $20\left[{ }^{\circ} \mathrm{C}\right]$ 以 下になるまでの時間は, $125[\mathrm{~min}], 55[\mathrm{~min}]$ となっており， 蓄熱体レンガ数が同一にもかかわらず，レンガを縦に置い て千鳥配列とした場合のほうが長い時間使用できるという ことになる.

Fig.6(a),(b)〜Fig.7(a),(b)は蓄熱・放熱過程における流れ 方向位置上のレンガの中心部の温度変化である.

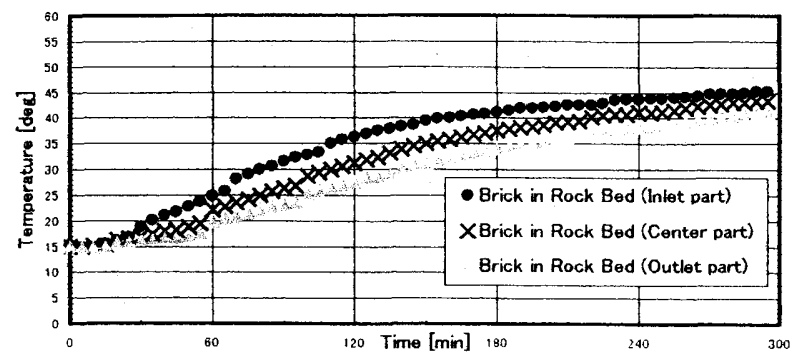

(a) Array 1

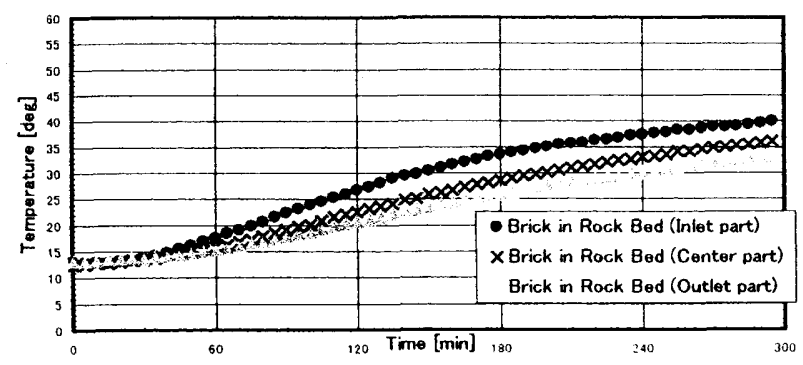

(b) Array 3

Fig.6 Transient Changes in Rock Bed Temperature (Charging)

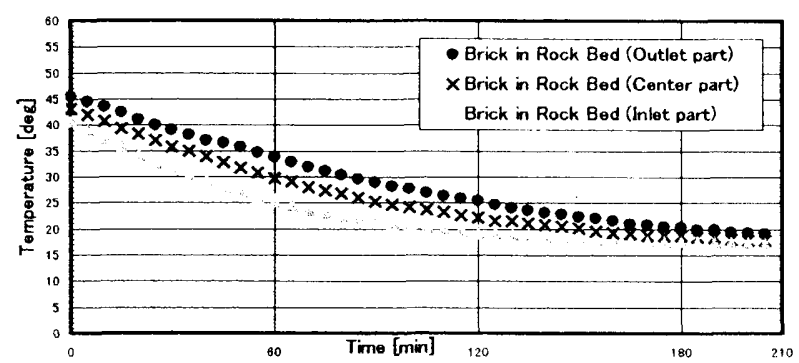

(a) Array 1

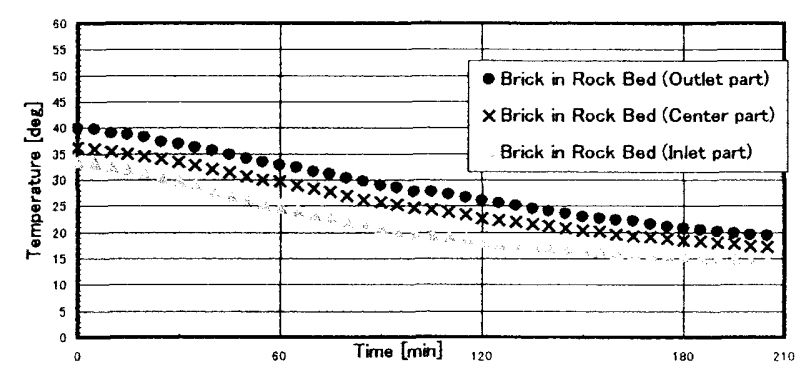

(b) Array 3

Fig.7 Transient Changes in Rock Bed Temperature (Discharging)

Fig.6(a),(b)より，蓄熱過程ではどのレンガ配列の場合も， 出口側より入口側のレンガのほうが温度が高くなっている. これは各条件に対して蓄熱槽に蓄えられた熱が，飽和状態 にはなっていないことを示している.すなわち, 熱源の効 率や質量流量などを変更することにより，さらに多く蓄熱 できるということである、レンガを縦に置いた場合と横に 置いた場合を比較してみると，レンガを縦に置いた場合の ほうが，蓄熱終了時のレンガ温度が高くなっているのがわ かる、これは、レンガを縦に並べて置いたことでレンガ間 に隙間が生まれ，その隙間を通過する空気によって，より 
多くの熱が入口から出口まで蓄えられたことや，レンガを 積み重ねた場合よりも，空気にふれるレンガの表面積，つ まり受熱面積が大きくなったことによるものである。

また Fig.7(a),(b)に示した放熱過程では，どのレンガ配列 の場合も出口側のレンガ温度の方が高くなっている．また 放熱過程の初期段階において，レンガ温度は大きく下降し ているが，その後，その下降の割合は城少しているという こともわかる，この傾向は，レンガを縦に置いた場合の蓄 熱槽入口側のレンガによく表れている.

Fig.8 は蓄熱終了時における，蓄熱槽長さ方向での各位 置上レンガ中心部の温度上昇の割合である．図から，横置 きよりも縦置きのほうが温度上昇の割合が高く，また千鳥 配列をした場合のほうが，基盤目の場合より温度上昇がか なり大きいということが読み取れる

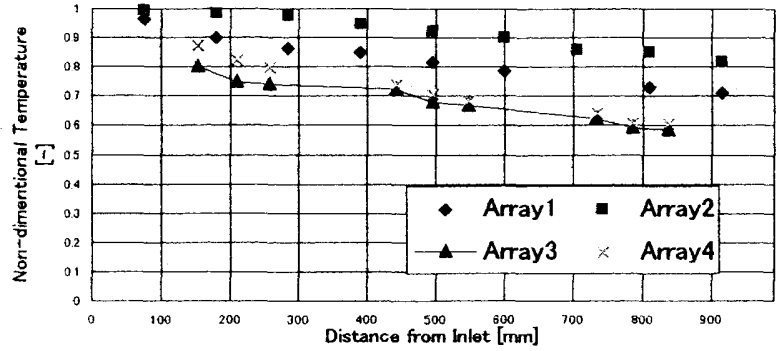

Fig.8 Effect of Rock Bed Arrangement on Temperature Distribution

Table1 Thermal Storage Efficiency in Rock Bed

\begin{tabular}{|c|c|c|c|}
\hline & 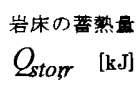 & $\begin{array}{c}\text { 空気が゙取り出した熱量 } \\
Q_{\text {disclair }}[\mathrm{k} \mathrm{s}]\end{array}$ & $Q_{\text {disgtiv }} / Q_{\text {star }}$ \\
\hline レンガ配列(1) & 968.83 & 817.22 & 0.8435 \\
\hline レンカ配列(2) & 913.83 & 840.72 & 0.9200 \\
\hline レンガ配列(3) & 746.44 & 591.84 & 0.7929 \\
\hline レンガ配列(4) & 768.17 & 663.56 & 0.8638 \\
\hline
\end{tabular}

Table1 は, 岩床の蓄熱量と空気が取り出した熱量を比較 したものである. Table1 を見てみると、レンガを縦に置い た場合（レンガ配列(1)，(2)）のほうが，横においた場合（レ ンガ配列(3), (4))よりも岩床一の蓄熱量が多くなっている. また千鳥配列をした場合（レンガ配列(2)，(4)）と碁盤目の 場合（レンガ配列(1)，(3)）の結果は，縦置きでは基盤目の 場合，横置きでは千鳥配列の場合が，わずかではあるが蓄 熱量が多くなっている。(1)のレンガ配列のときの蓄熱量が (2)よりも大きくなったのは，(1)式からも明らかなように， 岩床一の蓄熱量は蓄熱開始時と終了時のレンガの温度に依 存するので, 全体的な温度差が小さい(2)よりも，温度差は 多少大きくても蓄熱終了時のレンガ温度が高かったことに よっている.しかし、レンガの温度上昇の割合については,

Fig.8 に示したとおり，千鳥配列にした(2)のほうが高いた め，蓄熱量とレンガの温度上昇の割合が必ずしも相関関係 にあるとは言えず, 蓄熱槽入口の空気温度やレンガの配列 によってその熱的挙動は変わってくると考えられる。

また，空気が得た熱量は，レンガを縦に置いた場合（レ ンガ配列(1)，(2)）のほうが，横においた場合（レンガ配列 (3)，(4)）よりも，また縦置き・横置きどちらの場合も，千 鳥配列をした場合（レンガ配列(2)，(4)）のほうが，碁盤目
の場合（レンガ配列(1)，(3)）に比べて岩床から運び出した 熱量は多い，これはレンガを縦に置いたことによって空気 にふれるレンガの表面積が増え，また千鳥配列したことに よって，蓄熱槽内での空気の流れがスムーズになり，より 多くの熱がレンガから蓄熱槽外に運び出されている.

岩床の蓄熱量に対する有効エネルギの割合について Table1 を見てみると，レンガを縦に置いた場合 (レンガ配 列(1)，(2)）のほうが，横においた場合（レンガ配列(3)，(4)） よりも，また綐置き・横置きどちらの場合も，千鳥配列に した場合（レンガ配列(2)，(4)）のほうが，そうでない場合 （レンガ配列(1)，(3)）に比べて，岩床の蓄熱量に対する有 効エネルギの割合が多くなっていることが認められる。こ れはレンガを繸に置いたことによって空気にふれるレンガ の表面積が増え，また千鳥配列したことによって，蓄熱槽 内での空気の流れがレンガ表面全体に及び，より多くの熱 がレンガから蓄熱槽外に運び出されている。

\section{5. 結 言} 本実験的研究により得られた結果を以下に示す.

1.本実験においては，レンガを縦置きにすると伝熱面積が 増え, レンガに蓄えられる熱量も大きくなり温度上昇も 大きくなる.

2.蓄熱過程においてレンガを千鳥配列にすると，加熱空気 がより筧抖されるために槽内の対流熱伀達が促進され， 流れ方向の温度差が小さくなる，放熱過程においては, レンガを横置きにすると, レンガに蓄えられた熱量は早 い時間で放出され，一定温度以下になる。

3.蓄熱過程において蓄熱槽に蓄えられた熱量は，本実験で 用いた蓄熱槽に対して飽和状態になっておらず，より多 くの熱を蓄えることができる，そのためには，熱源から 流入する加熱空気の流れを円滑にし，蓄熱槽内における 流れ方向・高さ方向で，空気，レンガ間の熱交換を十分 に行わせるようなレンガ配列を設計する必要がある。

4.放熱過程において蓄熱槽から運び出される有効エネルギ 量は，どのレンガ配列の場合においても，レンガに貯蔵 されたエネルギ量より少なく，放熱の蓄熱量に対する比 は約 80〜92\%である. その割合は, 伝熱面積を増大させ る縦置きの場合，また，加熱空気の摫挥がより促進され る千鳥配列の場合に効果的である。

5.蓄熱終了時の温度上昇の割合，岩床の蓄熱量に対する有 効エネルギの割合，また放熱過程において，蓄熱槽出口 の空気温度が一定温度以下になるまでの時間（暖房とし て使用できる時間）などから，暖房性能を比較すると， レンガを縦に置いて千鳥配列をしたレンガ配列 2 が最も 良い性能を示している。

6.本研究での蓄熱層と, 蓄熱ユニットの寸法効果の重要因 子について基本的に蓄熱槽の断面積が蓄熱熱量を長さ方 向が蓄熱，放熱時間を規定するものと考えられるが，そ の解明は今後の課題とする.

\section{参考文献}

1. 岸浪紘機，勇田敏男，鈴木淳，他 3 名，“空気加熱式太 陽熱集熱器と岩床式蓄熱槽を組合せた採暖熱利用システム に関する基礎研究”, 第 19 回寒地シンポジウム講論, vol.19(2003),23-30 